\title{
Digital Education Environment in a Single Information and Education Space of the Region: Sverdlovsk Region Experience
}

\author{
Prostova D.M* . Tikhonova A.D. Sosnina N.G. \\ Ural State University of Economics, Ekaterinburg, Russia \\ *Corresponding author. Email: prostova@usue.ru
}

\begin{abstract}
Digitalization has become the largest technological revolution in the history of mankind, which has required significant changes and innovations in the management of socio-economic systems. In Russian pedagogical science digital transformation of education is considered as the process of modernization of the content, methods and organizational forms of teaching and educational work that takes place in a rapidly changing digital learning environment aimed at solution of socio-economic development tasks of the country in terms of the fourth industrial revolution and the development of the digital economy. As a result, the education system, along with the development of information infrastructure, is becoming a vector for the development of the digital economy in the Russian Federation.

The model of digital education developed by the authors, aimed at creating a single information and educational space in the region, provides not only training and education, but also effective integration of the individual into a high-tech rapidly changing complex environment. The educational ecosystem, performing the function of a structural core, is an integrative socio-cultural environment, in the center of which there is not a teacher of a traditional school, but the pupil, surrounded by peers and adults who help him to fulfill a personal learning path.

This model demonstrates the implementation of the goals set for the digital education environment by the digital economy to train high-tech personnel who possess digital competencies and are ready to receive education throughout their lives. The social order of society and households for a high level of professional and personal development in the conditions of digitalization of the economy is provided by the development of digital competencies set. The high level of digital literacy of teachers ensures that graduates are trained at a high technological level that meets the needs of a particular region, thereby ensuring expanded reproduction.

Keywords: digital education environment, digital economy, digital competences, information communicative
\end{abstract}

technologies, digital education platforms

\section{INTRODUCTION}

Modern economy is characterized by the penetration of digital technologies in all spheres of economic activity. As a result, new forms and methods of interaction of economic actors appear, as well as the functional load of all participants in the new digitalization process is changing.

Digital transformation processes, which affect business, government and society enable all stakeholders to obtain qualitatively new results from their activities, are resulting in aggregate economic development [1].

V.V. Putin at the St. Petersburg International Economic Forum announced the need to increase the number of specialists with a high level of digital literacy, assigning this responsibility to the education system.

The development of digital technologies doesn't contribute to qualitative changes only in production, but also in education. The pedagogical community sees the digital transformation of education as a process of changing the content, methods and organizational forms of teaching and educational work aimed at addressing the challenges of the country's socio-economic development in the context of the fourth industrial revolution and the establishment of a digital economy.

In the Russian Federation, the main conceptual documents regulating the development of information technologies in education are the following ones.

Federal Target Program "The Development of Single Learning Information Environment" (2001). The aim of the Program is to ensure the unity of the educational space throughout the country; to improve the quality of education in all regions of Russia; to preserve, develop and use the scientific and pedagogical potential of the country effectively; to create conditions for a phased transition to a new level of education based on information technologies and create conditions for the provision of Russian 
educational services to Russian-speaking population abroad. The Program was aimed at restoring the technological infrastructure of the education system, supplying educational institutions with computer equipment, connecting them to the Internet to access global information resources, to create and use digital teaching materials in the educational process [2].

As part of the state program implementation "The Development of Education for 2013-2020", the federal project "Modern Digital Educational Environment in the Russian Federation" was launched in 2016 г. The project was focused on the modernization of the education and training system in the context of the digital economy, on the introduction of digital learning tools and their inclusion in the information environment, as well as the possibility of training citizens according to an individual plan throughout their lives [3].

In order to develop the information infrastructure and improve the education system and the training of relevant personnel, the "Strategy for the Development of the Information Society in the Russian Federation for 20172030" was developed [4].

As representatives of the pedagogical community noted, over the years of the transition of education to the information format, some results have already been achieved. Due to the increase in funding, the Internet has been provided to each school, computer classes have been equipped, and teachers have been retrained.

One of the defining goals of the digital economy of the Russian Federation the program "Human Resources and Education" is the introduction of modern information technologies in the learning process, which has increased the technology and flexibility of education, as well as the motivation of pupils to master new practical knowledge and experience [4].

According to the Development Strategy, the proportion of the population with digital skills should reach $40 \%$ by 2024, which certainly requires significant changes from the entire teaching community, both in terms of the use of new information technologies (IT), changes in emphasis in education, and the improvement of competencies in information and communicative technologies (ICT competencies) and the development of digital skills of all participants of the educational process.

The ability to access large databases of information against the background of a significant increase in the speed of its dissemination changes the education and requires the pedagogical community to master new competencies due to a number of features: pupils need effective assistance in choosing, assessing the reliability, interpretation and analysis of available information [5].

The education system has a special role to play in the digitalization process: education, as a kind of a "bridge", should provide the Russian economy and society as a whole with a confident transition to the digital age, characterized by productivity growth and new labor relations [6].

The presented list of legislative documents of the Russian Federation illustrates the high level of state awareness of the importance of creating a single digital platform for training qualified personnel with the necessary set of digital competencies for the needs of the digital economy. However, the analysis of the structure, content and functioning of the educational process has revealed a number of problems that impede the implementation of the education digitalization. Let's look at the most significant problems.

Schools do not make sufficient use of digital technologies to motivate pupils. The education system continues to ignore digital tools, which children successfully use in their daily lives. Most general education establishments don't organize personalization of children education with special developmental needs (assistance with learning difficulties, variety of educational materials and choice of personal learning path). Digital technology is underutilized to facilitate educators and managers' daily duties (auditing, monitoring and reporting) [7]. It should be noted that the level of digital literacy possessed by teachers is insufficient.

Thus, there are the following contradictions that hinder the transition to digitalization in the education sector:

- between the increase in the technological sophistication of the educational process and the school's unpreparedness for the smooth functioning of ICTs;

- between the level of students' motivation to learn using ICTs and the inability of some teachers to use them in the educational process;

- between the presence of large amount of digital educational content in the information environment and the reluctance of the school to integrate it properly into the educational process.

The aim of this study is to build a model of digital education environment aimed at developing a single information and educational space in the region that meets the requirements of strategic development of digital economy. The objectives of the study are the following:

- To explore the legal framework for digital transformation of education.

- To determine the structure and content of the digital educational environment.

- To develop a model of digital educational environment aimed at developing a single information and education space of the region.

- To analyze the development level of digital educational environment in the economic area in Sverdlovsk region.

- To make conclusions and provide steps for further development.

\section{METHODOLOGY}

This research is aimed at examining the level of educational system transformation in the context of digitalization, to determine the degree of schools readiness for the transition to the inclusion of ICT in the process of training graduates with the necessary digital competencies. 
The authors used logical and systematic methods of analysis as research methods. The specifics of the problems determined the structure of the research being conducted. The authors have analyzed the indicators of digitalization and the intensity of use of digital technologies in the educational system. The digital educational environment has been modeled to meet the requirements of the digital economy.

The research algorithm included the following steps:

- the study of scientific research devoted to the directions of development of the digital educational system;

- the identification of the development level of education digitalization;

- the summarizing of the authors' vision of the digital transformation processes of the educational environment.

\section{THE MODEL OF DIGITAL EDUCATION ENVIRONMENT}

Digitalization has become the largest technological revolution in the history of mankind, which has required significant changes and innovations in the management of socio-economic systems. Education as one of the socioeconomic systems was the first to respond to the challenges of the new direction of development.

In Russian pedagogical science digital transformation of education is considered as the process of modernization of the content, methods and organizational forms of teaching and educational work that takes place in a rapidly changing digital education environment aimed at solution of socio-economic development tasks of the country in terms of the fourth industrial revolution and the development of digital economy. As a result, the education system, along with the development of information infrastructure, is becoming a vector for the development of the digital economy in the Russian Federation.

Consumers of digital transformation of education are the state, production, business, society and households. The state through education solves global issues of strategic development, uniting the nation, and strengthening its competitive position on the world stage.

The production and business sector is interested in high scientific and technological potential to create competitive advantages and in highly qualified personnel that meet the requirements of the rapidly developing digital economy [8].

The acquisition of social stability and social development of citizens is of fundamental importance for society. Households are interested in personal and professional self-realization and social success.

The emergence of the term "digitalization" was associated with the intensive development of information and communication technologies. D. K. Schwab called the first digital revolution of the 1960s and 1980s "industrial", believing that its catalyst was the development of semiconductor computers, in the 60 s and 70 s - personal computers, in the 90s - the Internet [9].

Digitalization of education is a transition to a radically new education environment that uses ICTs as the main tools. Let us consider different view points on the content of this concept.

In a foreign pedagogical school, there is an opinion that digital education is a new learning tool with opportunities in the place where the employee is located [10].

The Russian school is of the opinion that the digitalization of education radically changes not only the tools of the teacher and the pupil, but also focuses on new learning outcomes that meet the needs of the new digital economy [11].

Some Russian authors limit themselves to include new digital tools for teachers and pupils in understanding digital education (V.N. Pogodin [12], N.YU. Ignatova [13], M.E. Kushnir [14], I.YU. Travkin [15]).

However, recent research reflects a deeper understanding of the digitalization of education.

A.M. Kondakov and A.A. Kostyleva define digital education as an educational activity aimed at developing skills in digital data processing, which results in the possibility of functioning of the individual in a new sociocultural situation. The authors call the new direction in education "digital school", which provides effective integration of the individual in a high-tech, rapidly changing complex environment. Thus, the educational ecosystem is an integrative socio-cultural environment, in the center of which there is not a teacher of a traditional school, but a pupil, surrounded by peers and adults who help him to fulfill a personal learning path [8]. This position clearly illustrates the requirements of the digital economy for education to train new competent personnel.

M.E. Vajndorf-Sysoeva and M.L Subocheva are of the opinion that digital education is traditional education in a new digital format with mandatory use of digital resources, interaction with IT engineering, business, science, and society» [16]. This vision reflects the need for the educational industry to interact with the manufacturing industry and the business community.

Summarizing the above opinions, in the context of this research, we understand digital education as the process of graduates' competencies development that meets the conditions of globalization and the digital economy. Digital education prepares pupils to become digital citizens by motivating them to acquire navigation skills in the digital world [17].

Digital education is a kind of training with the use of digital technologies in various areas of human activity. It helps to develop students' digital literacy and prepare them for the global, digital labor market and social life [18].

The content of digital education remains a topical issue today. There are different ideas what distinguish traditional education from its digital form.

Today, the creation of a digital educational environment in an educational organization is a justified necessity. A modern school should train such a graduate who will have a certain set of digital competencies, and will be aimed at 
information and educational space of the region that meets the requirements of strategic development of digital economy [Appendix 1].

The educational process within the framework of the developed model provides not only training and education, but also effective integration of the individual into a hightech rapidly changing complex environment. The educational ecosystem, performing the function of a structural core, is an integrative socio-cultural environment, in the center of which there is not the teacher of a traditional school, but the pupil, surrounded by peers and adults who help him to realize a personal educational path.

This model demonstrates the implementation of the DEE goals set for digital economy to train high-tech personnel who possess digital competencies and are ready to receive lifelong education. The social order of society and households for a high level of professional and personal development in the conditions of digitalization of the economy is provided by the development of the necessary digital competencies set of pupils. The high level of digital literacy of teachers ensures that graduates are trained at a high technological level that meets the needs of a particular region, thereby ensuring expanded reproduction.

\section{THE DISCUSSION OF THE RESEARCH RESULTS}

A number of key aspects should be taken into account when developing the DEE in an educational organization [Table 1]:

- the provision of the educational organization with the necessary equipment;

- the opportunities to introduce information and communication technologies in the practice of teaching all academic subjects;

- the level of formation of ICT competence of teachers;

- the conditions for practical application of computer technology and other digital tools by all participants of educational relations;

- the possibility of free access to information channels of the local internal network, to the global Internet and to the resources of the media library.
Based on the analysis of the legal regulation of the education digitalization process, as well as taking into account the above-structured content of the DEE, a model of DEE was created that aimed at developing a single 
Table 1 The Main Components of DEE

\begin{tabular}{|c|c|}
\hline Main Components & FSES Compliance \\
\hline school official website & provides information and methodological support for the educational process \\
\hline e-mail & provides information and methodological support for the educational process \\
\hline e-journal & $\begin{array}{l}\text { provides planning of the educational process and its resource support, monitoring and } \\
\text { recording the progress and results of the educational process }\end{array}$ \\
\hline electronic calendar & provides educational process planning and its resource support \\
\hline electronic document management system & $\begin{array}{l}\text { provides modern process for creation, search, collection, analysis, processing, storage and } \\
\text { presentation of information }\end{array}$ \\
\hline Distance Learning System for Students & $\begin{array}{l}\text { provides remote interaction of all participants in the educational process (students, their } \\
\text { parents (legal representatives), teachers, educational authorities, the public), including in } \\
\text { the framework of distance education }\end{array}$ \\
\hline corporate portal & provides the development of ICT competence of the pedagogical staff \\
\hline support system for computer users & $\begin{array}{l}\text { provides conditions for practical application of computer equipment by participants of } \\
\text { educational process }\end{array}$ \\
\hline
\end{tabular}

The analysis of the state of each structural component of the DSP of the Sverdlovsk region is presented for further consideration.

For further consideration, we will present an analysis of each structural component development level of the DEE of the Sverdlovsk region.
For the beginning of 2019 , there are 1523 educational institutions of general education in the Sverdlovsk region. The volume of incoming funds increases annually, so in 2017 there was an increase in funding by $6 \%$, and in 2018 - by $7 \%$ [Table 2]. The number of personal computers used for monitoring and managing educational organizations increased by $4 \%$ in 2017 , and only by $2 \%$ in 2018 [Table 3].

Table 2 The Financing of Educational Establishments of General Education

\begin{tabular}{|l|l|}
\hline Year & Financing \\
\hline 2016 & 34603866.3 \\
\hline 2017 & 36830691.2 \\
\hline 2018 & 39947044.8 \\
\hline
\end{tabular}

Table 3 Personal Computers for Administration Purposes

\begin{tabular}{|l|l|}
\hline Year & Total Amount of Personal Computers \\
\hline 2016 & 90213 \\
\hline 2017 & 94101 \\
\hline 2018 & 96930 \\
\hline
\end{tabular}

The number of personal computers used for educational purposes has the same downward trend. In 2017, there was an increase in the number of computers by $4.3 \%$, while in 2018 - by only $2.7 \%$ [Table 4]. 
Table 4 Personal Computers for Education Purposes

\begin{tabular}{|l|l|}
\hline Year & Total Amount of Personal Computers \\
\hline 2016 & 77212 \\
\hline 2017 & 80731 \\
\hline 2018 & 83014 \\
\hline
\end{tabular}

Based on economic feasibility, as well as in compliance with the decree of the President of the Russian Federation «On national goals and strategic objectives of the development of the Russian Federation for the period up to 2024» digital educational environment functioning is based on working with freely distributed and domestic software. An important criterion for creating a DEE is an access to all services via the browser and the multiplatformness of the tools used, which provides flexibility of configuration, mobility and ease of operation for all participants of the educational process.

For further analysis, we will present a list of digital platforms recommended by the Ministry of Education of the Russian Federation [Appendix 2].

Today, a large number of educational platforms are open access in the digital space. For system analysis, the authors selected platforms that are particularly popular among teachers of the Sverdlovsk region. The structural components of each educational system served as criteria for the analysis: video demonstrations, the ability for further skill's development, monitoring and testing, feedback, interaction with parents, individual learning path, information educational and methodological base, retraining of teachers, career guidance and free access.

As shown in the table [Appendix 2], the majority of digital services implement the priority of motivation for each participant in the educational process, monitoring results and providing feedback. Interaction with parents emphasizes the importance of their participation in the process of personal and professional development of the child.

The ability to build a personal learning path implements the principles of the traditional personality-oriented approach in a new digital format.

Some platforms provide an opportunity to retrain teachers in the context of new digital competencies, which solves the problem of qualified personnel lack for a new school in the era of digitalization.

However, it should be emphasized that the digital platform complements well-functioning traditional teaching methods and replaces ineffective ones. It uses the potential of high technologies and artificial intelligence to provide opportunities for individual choice, prompt feedback, and the use of modern media texts, videos, graphics, infographics, and simulators. However, the platform does not replace the teacher: his role as a mentor, tutor, and navigator in the educational process is key aspect. The platform contains tools for developing children's skills of the XXI century: the ability to set goals and achieve them, work in a team, understand oneselves and others, be creative and think critically [19].

The presented list of digital educational platforms demonstrates a sufficient level of implementation of the requirements for the availability of digital educational resources in educational organizations. However, as practice shows, the insufficient level of digital literacy of the teaching staff and administration of educational institutions hinders the smooth integration of digital educational platforms into the learning process. In addition, some of the most user-friendly adapted resources are partially freely available, offering free demo versions and a limited set of options, which, in turn, creates significant barriers for educational institutions and households to use them.

As it can be seen from the presented analysis of the amount of funding, the development level of digital educational content and the level of digital training of teaching staff, it should be marked that the last aspect causes the greatest problem.

Unfortunately, computer literacy of school teachers is not always at a high, and in the current situation, it directly affects the educational process. The routine work transformed into the digital format takes up even more time for the teacher that he could spend on retraining and mastering new digital technologies. In this situation, teachers need fairly prompt technical support and good advice from a technical specialist.

In the Sverdlovsk region, the Institute for Education Development is implementing a retraining program for teachers. The Institute has a wide variety of internship programs, seminars, master classes, video conferences and forums. The main goal of the retraining program is not only to organize a modern process of professional development of teachers and managers, but also to introduce modern forms and technologies of organization of students' activities in educational organizations.

Recently, the Institute has implemented the project "School of Distance Learning", which aims to create a single information education space of the region, the development and implementation of distance learning programs for pupils of educational institutions of Sverdlovsk region. However, this project covers only $4 \%$ of educational organizations in the Sverdlovsk region, and only $1.8 \%$ of pupils are active participants in the Institute's digital projects. 
[4] Programma «Cifrovaya e’konomika Rossijskoj Federacii», utverzhdennaya rasporyazheniem Pravitel`stva Rossijskoj Federacii ot 28.07.2017 №1632-r [E`lektronny`j resurs]. - Rezhim dostupa: http://static.government.ru/media/files/9gFM4FHj4PsB 79I5v7yLVuPgu4bvR7M0.pdf

[5] Koly`xmatov V.I. Sovremenny`e cifrovy`e obrazovatel`ny`e texnologii $\mathrm{v}$ shkolax Leningradskoj oblasti v usloviyax cifrovizacii obrazovaniya. Ucheny`e zapiski universiteta imeni P.F. Lesgafta. - 2018. - № 8 (162) s. 87

[6] Avadaeva I.V. i dr. Metodologicheskie osnovy formirovaniya sovremennoj cifrovoj obrazovatel' noj sredy`: monografiya. - Nizhnij Novgorod: NOO «Professional'naya nauka». - 2018. - $175 \mathrm{~s}$.

[7] Medvedeva E.I., Kroshilin S.V. Negativny`e aspekty` informatizacii obshhestva //E konomicheskij zhurnal. - 2013. - №. - S. 108-126.

[8] Kondakov A.M., Kosty`leva A.A. Vestnik RUDN. Seriya: Informatizaciya obrazovaniya. 2019. T. 16. № 4. S. $295-307$

[9] Laptev V. V. Metodologiya vizualizacii. - M. : Mir, 2011 - $304 \mathrm{~s}$.

[10] Bersin J. The Disruption of Digital Learning: Ten Things We Have Learned. [Электронный ресурс]. URL: https://joshbersin.com/2017/03/the-disruption-ofdigital-learning-tenthings-we-have-learned/2017

[11] Prikhodko O.V. (2020). Features of formation of digital competence of university students. Azimuth of Scientific Research: Pedagogy and Psychology, 1 (30), 235-238.

[12] Pogodin V.N. Obrazovanie «V cifre» - vzglyad iznutri [E`lektronny`j resurs] // Vesti obrazovaniya: [sajt]. 2017. Sentyabr`. URL: https://vogazeta.ru/articles/2017/9/20/analitycs/248obrazovanie_v_tsifre_vzglyad_iznutri

[13] Ignatova N.Yu. Obrazovanie v cifrovuyu e'poxu: monografiya. Nizhnij Tagil, $2017.128 \mathrm{~s}$

[14] Cifrovaya obrazovatel 'naya sreda // Direktoriya onlajn. [E`lektronny`j resurs] URL: https://medium.com/direktoria-online/the-digitallearning-environment-f1255d06942a 2017

[15] Travkin I.Yu. O cifrovoj obrazovatel'noj srede i drugie soputstvuyushhie my`sli [E`lektronny`j resurs] // Fun of Teaching: [sajt]. [26.04.2017]. URL:
[3] Kashina E.A. Prognozirovanie struktury integrirovannogo kursa informatiki : dis. ... kand. ped. nauk. - Ekaterinburg, 1997 - 187 s. 
eaching.

http://funoft

tumblr.com/post/160011857841/o-cifrovoj-

obrazovatel`noj-srede-i-drugie

[16] Vajndorf-Sy`soeva M.E., Subocheva M.L. «Cifrovoe obrazovanie» kak sistemoobrazuyushhaya kategoriya: podxody` k opredeleniyu // Vestn. Mosk. gos. obl. un-ta. Ser.: Pedagogika. 2018. №3. S. 25-35.

[17] Dmitrova A.V. (2020). Theoretical aspects of digital literacy formation: features of representation in pedagogical research. Azimuth of Scientific Research: Pedagogy and Psychology, 1 (30), 111-114.

[18] Zonova M.V., Nikalaeva N.A., Sosnina N.G. Digital communicative technologies as a means of developing cognitive activity in English classes at a non-linguistic university // Modern management trends and the digital economy: from regional development to global economic growth: proceedings of the $1 \mathrm{st}$ international scientific conference. - Atlantis Press. 2019. - V.81. - P. 609-613.

[19] Vklad V budushhee: blagotvoritel’ny`j fond Sberbanka» [E’lektronny'jresurs] https://vbudushee.ru/about/news/shkolnikov-

podklyuchat-k-unikalnoy-platforme-sberbanka/ 